УДК 336.143.01

DOI: https://doi.org/10.37320/2415-3583/10.25

Цимбалюк I.O.

кандидат економічних наук, доцент, Східноєвропейський національний університет імені Лесі Украӥнки ORCID: https://orcid.org/0000-0003-0506-2262

\title{
СУТНІСТЬ ТА СКЛАДНИКИ ФІСКАЛЬНОГО ПРОСТОРУ ІНКЛЮЗИВНОГО РОЗВИТКУ РЕГІОНІВ
}

\begin{abstract}
У статті розкрито сутність фіскального простору регіону як середовища взаємодї між економічними суб 'єктами та органами самоврядування стосовно перерозподілу фінансових ресурсів регіону. Визначено детермінанти формування та розширення фіскального простору регіону, а саме: орієнтири та механізми фіскальної політики; бюджетний устрій і структура бюджетної системи; величина податкового потенціалу території. Доведено, щзо фіскальний простір регіонів обмежується впливом фіскальної політики держави, орієнтири та відповідні механізми реалізації якої через законодавче встановлення визначають рамки можливостей економічних суб'єктів приймати самостійні рішення й впливати на прочес акумулювання та використання фінансових ресурсів у бюджетах певного рівня. Обгрунтовано авторське бачення поняття «фіскальний простір інклюзивного розвитку регіону», щзо дає змогу поглибити розуміння иієї дефініції та її иільової спрямованості. Виокремлено детермінанти виникнення негативних ефектів фіскального простору регіону.
\end{abstract}

Ключові слова: фіскальний простір регіону, фіскальний простір інклюзивного розвитку регіону, інклюзивний розвиток регіону, фінансова децентралізаџія, фіскальна політика, бюджетна система, податковий потенціал.

Постановка проблеми. Проблема пошуку оптимальної моделі розвитку регіону як просторової системи $\epsilon$ фундаментальною 3 теоретичного та практичного погляду й не втрачає своєї актуальності. Здатність побачити просторову систему у цілому, вміння розкрити зв'язки та взаємодії між окремими iii складниками в їх динаміці $€$ найбільш важливими умовами забезпечення регіонального розвитку.

Розвиток регіону як просторової системи зумовлюється диференціацією суспільних потреб і потребує мобілізації фінансових ресурсів, здійснення оптимальних бюджетних видатків, державних запозичень у межах бюджетних обмежень, що в комплексі суттєво впливає на процеси формування та виникнення коливань фіскального простору.

Дотепер немає усталеного трактування економічного змісту дефініції фіскального простору та недостатньо чітко визначений комплекс інструментів, застосування яких дасть змогу активізувати інклюзивний розвиток регіону в умовах фінансової децентралізації.

Аналіз останніх досліджень і публікацій. Дослідженню економічного змісту фіскального простору присвячено численні праці вітчизняних та закордонних учених, систематизація та критичний аналіз яких свідчить про існування різнобічних наукових підходів до визначення цієї дефініції.

Досліджуючи сутність фіскального простору та його взаємозв'язок із фінансовою стійкістю, П. Хеллер розуміє його «як наявність бюджетних можливостей уряду забезпечити ресурси для досягнення бажаних цілей, не завдаючи шкоди стійкості урядовій фінансовій позиції» [1, с. 4]. Позитивом у визначенні $€$ посилання на концепцію фінансової стійкості. Погляди П. Хеллера розділяє група вчених Науково-дослідного відділу Міжнародного валютного фонду (Jonathan D. Ostry, Atish R. Ghosh, Jun I. Kim, Mahvash S. Qureshi) [2]. Розглядаючи фіскальний простір на рівні держави у цілому, під фіскальним простором вони мають на увазі можливості для подальшого збільшення державного боргу без підриву фінансової стійкості держави. Бачення фіскального простору за такого підходу стосується спроможності уряду, принаймні у майбутньому, фінансувати бажані програми витрат, обслуговувати будь-які боргові зобов'язання (включаючи ті, які можуть виникнути, якщо створений фіскальний простір виникає за рахунок державних запозичень) та забезпечувати його платоспроможність. Однак таке трактування досить однобоко розглядає можливість формування додаткових фінансових ресурсів, обмежуючись лише рамками бюджету. На нашу думку, фіскальний простір охоплює усе середовище взаємовідносин суб'єктів господарювання щодо сплати податків, формування джерел доходів бюджету, а також середовище здійснення видатків, що розширяє рамки простору за межі, окреслені перерозподілом акумульованих у бюджеті ресурсів.

T. Затонацька та О. Ткаченко [3, с. 121-122], досліджуючи проблематику визначення фіскального простору різними науковцями, узагальнюють чотири підходи до наукового бачення його сутності: цільовий, кількісний, ресурсний, витратний та результатний. Оцінивши переваги та упущення кожного із цих підходів, автори трактують фіскальний простір як обсяг фінансових ресурсів, сформованих державою в результаті провадження активної фіскальної політки, за рахунок мобілізації надходжень 
до державного та місцевих бюджетів, раціоналізації бюджетних видатків, здійснення державних запозичень у межах бюджетних обмежень, формування фондів для забезпечення реалізації функцій держави та в цілях їі соціально-економічного розвитку. Подане визначення враховує цільову спрямованість та ідентифікує джерела формування фіскального простору, підкреслює його взаємозв'язок із провадженням активної фіскальної політики. Водночас ресурсний підхід до трактування фіскального простору та ототожнення 3 фінансовими ресурсами, сформованими у результаті провадження фіскальної політики, на нашу думку, дуже звужує розуміння сутності цієї дефініції.

Концепція фіскального простору на рівні центрального уряду та місцевих органів влади має низку відмінностей, які зумовлюються обмеженістю можливостей місцевої влади щодо впливу на формування дохідної частини бюджету.

Як зазначає Л. Аджієва, фіскальний простір регіону виступає об'єктом бюджетно-податкової політики та являє собою можливий обсяг фінансових ресурсів регіону, які визначаються, з одного боку, величиною бюджетно-податкового потенціалу, трансфертів та позик, а з іншого - раціоналізацією бюджетних витрат $[4$, с. 9-10]. У цьому визначенні обмежувачами фіскального простору автор називає, з одного боку, можливість наповнення бюджету, а з іншого - визначення шляхів та обсягів витрат акумульованих у бюджеті ресурсів. На нашу думку, дохідна частина бюджету значною мірою залежить від інструментів та механізмів фіскальної політики, які встановлені державою та щодо яких частковими повноваженнями наділені місцеві самоврядні органи. Що стосується податкового потенціалу, то це поняття охоплює можливі надходження податкових платежів залежно від податкової бази, що формується на визначеній території за певний період. Отже, на формування податкового потенціалу безпосередньо впливає низка окремих чинників: чисельність населення, розвиток бізнесу, територія та наявність на ній ресурсів розвитку тощо. Зважаючи на це, величину бюджетно-податкового потенціалу варто виділити в окремий обмежувач фіскального простору.

3 точки зору Ю. Кузькіна, фіскальний простір місцевого самоврядування являє собою сукупність локалізованих у межах певної території економічних процесів і господарських відносин, результати здійснення яких у рамках дії податкового та бюджетного механізмів держави визначають на основі розроблення та реалізації активної фіскальної політики. А також фінансовий потенціал, що може бути використаний для реалізації органами самоврядування (у межах наданих ним прав і повноважень) на місцевому рівні діапазону рішень у сфері регіонального розвитку в межах дотримання вимог і обмежень щодо збереження стійкості фінансового стану держави та іiі регіонів. Ключовими елементами фіскального простору при цьому автор називає податковий потенціал, бюджетний потенціал, бюджетну ємність [5]. Погоджуємося 3 думкою автора щодо значимості податкового та бюджетного механізмів держави у формуванні фіскального простору, однак об’ємності такій структурі надаватиме податковий потенціал.

Мета статті полягає у визначенні сутності та складників фіскального простору інклюзивного розвитку регіонів, розкритті основних детермінант його формування та розширення, якими $€$ орієнтири та механізми фіскальної політики, бюджетний устрій і бюджетна система, а також податковий потенціал території.

Виклад основного матеріалу. Наукове бачення сутності простору наділяє його такими властивостями, як тривимірність, однорідність, структурність, протяжність, співіснування й взаємодія елементів у всіх матеріальних системах. Тривимірність простору - фундаментальна властивість, що емпірично констатується, виражається у тому, що положення будь-якого об'єкта можна визначити за допомогою трьох незалежних величин: довжини, висоти, ширини. Грунтуючись на цих базових, вихідних характеристиках простору як такого, сформулюємо власне авторське бачення фіскального простору регіону.

Фіскальний простір регіону - це середовище взаємодії між економічними суб'єктами та органами самоврядування стосовно перерозподілу фінансових ресурсів регіону, детермінантами формування та розширення якого є: орієнтири та механізми фіскальної політики; бюджетний устрій і структура бюджетної системи; величина податкового потенціалу території (рис. 1).

Фіскальний простір регіонів обмежується впливом фіскальної політики держави, орієнтири та відповідні механізми реалізації якої через законодавче встановлення визначають рамки можливостей економічних суб'єктів приймати самостійні рішення й впливати на процес акумулювання та використання фінансових ресурсів у бюджетах певного рівня.

Суб'єктами здійснення фіскальної політики $\epsilon$ органи державної влади, які представлені профільними міністерствами та відомствами: Міністерством фінансів України, Комітетом із питань податкової та митної політики, Державною податковою службою України, Кабінетом Міністрів України, Президентом України та іншими державними органами, які здійснюють вплив на формування фіскальної політики, визначення iï орієнтирів (Комітет із питань антикорупційної політики, Міністерство розвитку громад та територій, Міністерство соціальної політики та ін.). Об'єктами фіскальної політики є формування 


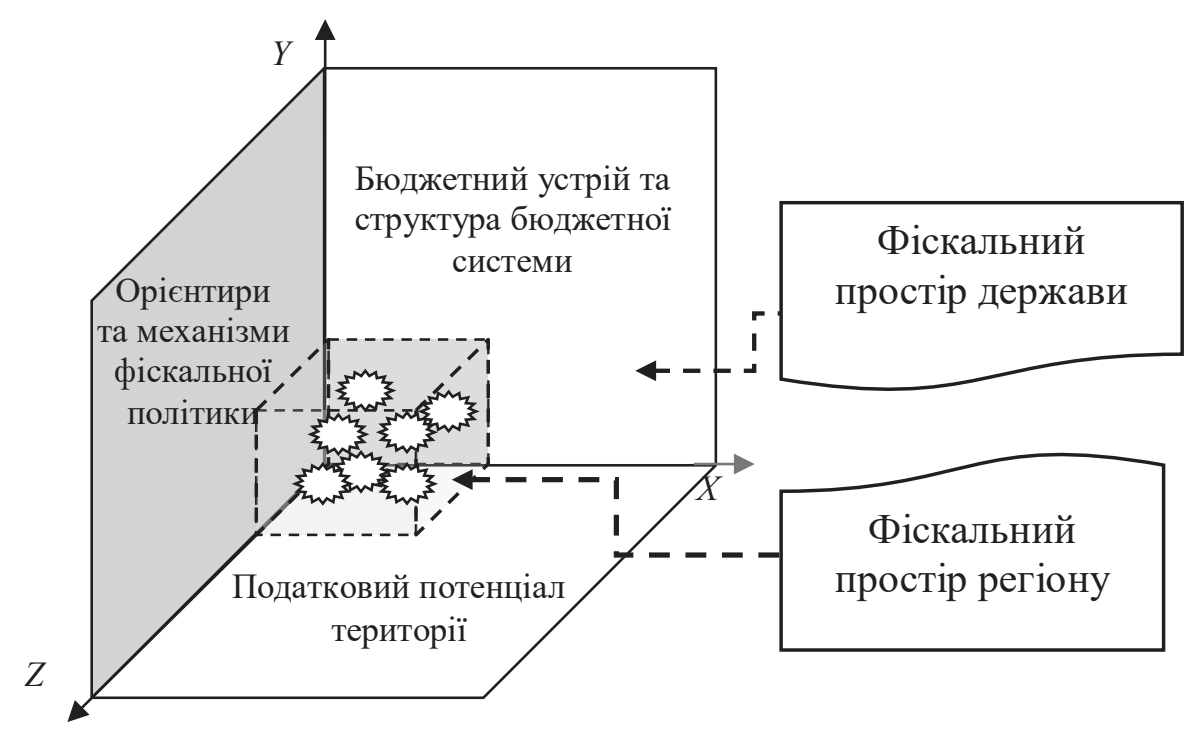

Рис. 1. Концептуальна схема фіскального простору регіону

Джерело: розроблено автором

та реалізація ефективно діючих податкової та бюджетної систем, визначення механізму використання відповідних їм інструментів, що дають змогу акумулювати фінансові ресурси та розподіляти їх на встановлені цілі розвитку.

Узагальнюючи наведені вище підходи, можна відзначити, що сутність фіскальної політики зводиться до здійснення діяльності уряду у сфері управління державними доходами і видатками. Використовуючи бюджетно-податковий інструментарій, держава може впливати на розвиток тих чи інших галузей та змінювати структуру національної економіки, стримувати інфляцію, стимулювати зростання національного виробництва та зайнятості, що в подальшому визначає напрями регіонального розвитку, впливає на формування доходів, які будуть оподатковуватися. Таким чином, сукупність інструментів, методів, фіскальної політики виступає певним обмеженням, визначаючи ємність та вектор розвитку фіскального середовища країни і регіонів.

Полемізуючи довкола спрямованості фіскальної політики, варто зазначити, що на практиці вона може сприяти розширенню, згортанню або стабілізації фіскального простору. Основним важелем фіскальної політики держави є зміна структури податків, насамперед зміна податкових ставок згідно із цілями розвитку, визначеними урядом.

Думки науковців часто сходяться у тому, що характеристикою фіскального простору $\epsilon$ бюджетна структура, організаційне та інституиійне забезпечення ї̈ функиіонування. Адже можливості уряду щодо маневрування обсягами та напрямами здійснення видатків прямо залежать від виду бюджету та повноважень відповідного рівня влади щодо здійснення бюджетного процесу. Структура бюджетної системи визна- чається ступенем розподілу повноважень із концентрації фінансових ресурсів та їх використання між органами публічної влади різного рівня. Вона залежить від державного устрою та адміністративно-територіального поділу країни. Своєю чергою, бюджетний процес охоплює сукупність дій уповноважених органів держави та місцевого самоврядування щодо складання, розгляду й затвердження бюджетів, а також звітів про їх виконання та здійснення контролю над дотриманням бюджетного законодавства.

Динаміка фіскального простору залежить від інституиійної системи, яка визначає здатність місцевих органів влади до регулювання обсягів доходів та видатків, рівня фінансової кредитоспроможності регіональної влади, екзогенних чинників впливу, здатності фінансових ринків фінансувати бюджетні проєкти [6]. За умов фінансової децентралізації розширення фіскального простору регіону досягається збільшенням реальних фінансових та правових можливостей місцевих органів влади, посиленням вагомості прийнятих ними управлінських рішень щодо формування та використання бюджетних ресурсів, можливості їх спрямування на активізацію інклюзивного розвитку.

Здійснюючи дослідження фіскального простору, неможливо не відзначити його визначальну роль у формуванні податкового потенціалу територій (ОТГ, регіону, країни).

Погоджуючись із думкою О. Башуцької [7], вважаємо, що податковий потенціал регіону відображає граничну величину податкових доходів, які можуть бути акумульовані місцевими органами самоврядування на підставі діючих норм податкової системи та зумовлюються податковою спроможністю економічних суб' єктів регіону. 
С.А. Супруненко визначає податковий потенціал регіону як регіональні фінансові можливості щодо відтворення податкових надходжень у бюджетну систему виходячи 3 оподатковуваної бази, що склалася в регіоні, без негативного впливу на суб'єктів господарювання [8]. Заслуговує уваги акцентування науковця на відсутності негативного впливу від реалізації податкового потенціалу регіону на діяльність суб' єктів господарювання.

Загалом податковий потенціал виступає теоретичною категорією, i, на нашу думку, його можна визначити як прогнозний обсяг податкових надходжень до бюджетів усіх рівнів, який реалізується через систему взаємодії податкового законодавства, органів податкової служби та платників податків із метою максимально наповнення бюджетів фінансовими ресурсами 3 урахуванням мінімально можливих утрат платників податків для стимулювання економічно необхідних процесів у державі [9].

Концепція фіскального простору виходить із визнання необхідності суттєвого збільшення ролі та підвищення значення податково-бюджетних важелів у процесі регулювання інклюзивним розвитком регіонів.

Вплив фіскального простору на активізацію інклюзивного розвитку регіонів проявляється через виявлення резервів збільшення доходів місцевих бюджетів та посилення видатків на досягнення визначених інклюзивно орієнтованих цілей. Вирішення цих завдань потребує узгодження державних та регіональних пріоритетів із цілями інклюзивного зростання, забезпечення фінансової стійкості та фінансової спроможності регіону і територіальних громад, що його формують.

Фіскальний простір інклюзивного розвитку регіону - можливості органів місцевого самоврядування щодо акумулювання та нарощення фінансових ресурсів, зумовлені діючими механізмами фіскальної політики, особливостями міжбюджетних відносин та величиною податкового потенціалу території, для здійснення оптимальних видатків, орієнтованих на максимізацію соціального добробуту, що досягається поєднанням економічної стабільності, ефективним перерозподілом акумульованих у регіональних бюджетах ресурсів та справедливим розподілом отриманих у результаті соціально-економічного піднесення благ.

Фіскальний простір регіону під впливом внутрішніх і зовнішніх чинників зазнає певних змін, які по-різному впливають на інклюзивний розвиток. Важливим аспектом при цьому є визначення причин виникнення негативних ефектів та ix ідентифікація задля здійснення ефективного управління фіскальними інструментами 3 метою мінімізації ризиків і розбалансованості регіонального розвитку, а також зменшення рівня соціальної напруги.
Серед детермінант виникнення негативних ефектів фіскального простору регіону варто виділити:

1. Негативний вплив фіскальної політики на формування бізнес-середовища регіонів. Зокрема, незначна роль системи місцевого оподаткування та суттєві обмеження повноважень місцевих органів самоврядування щодо їх встановлення нівелюють стимули до розвитку підприємництва i, таким чином, розширення податкової бази; підвищення якості контролю над сплатою податків тощо.

2. Неоптимальне використання ресурсів місцевих бюджетів. Фіскальний простір поряд із відносинами щодо акумулювання фінансових ресурсів у місцевих бюджетах охоплює питання визначення напрямів їх використання, і саме воно $є$ визначальним у контексті забезпечення розвитку регіону та дотримання орієнтирів інклюзивності. Значні витрати на утримання управлінського апарату при цьому значно обмежують ресурси для забезпечення регіонального розвитку, що набуває форми негативних ефектів фіскального простору.

3. Проблеми 3 нагромадженням необхідних ресурсів для реалізації програм інклюзивного розвитку регіону. Складна економічна ситуація в регіоні досить часто не дає змоги накопичувати i спрямовувати кошти на досягнення стратегічних орієнтирів, якими в умовах українських реалій мають стати цілі інклюзивного розвитку. Наявні ресурси в першу чергу використовуються для вирішення поточних проблем регіону і досить часто не мають продуманої стратегії та системності заходів, що фінансуються. Негативний вплив додає відсутність спеціалізованих кадрів та досвіду управління регіоном на засадах самодостатності та саморозвитку. У сукупності досить часто це $\epsilon$ причиною формування фінансово неспроможних регіонів та хронічної нестачі коштів для реалізації програм інклюзивного розвитку.

4. Неефективне використання людських ресурсів регіону, втрата інтелектуального капіталу. Ця проблема особливо гостро постає для відсталих та трудодефіцитних регіонів (зокрема, гірські території та райони Полісся), а також для прикордонних регіонів, де внаслідок суттєвої різниці оплати праці в Україні та за кордоном міграція трудових ресурсів набула масового характеру [10].

Отже, саме оптимальні параметри фіскального простору можуть стати дієвим чинником активізації інклюзивного розвитку регіонів. Натомість негативні ефекти розбалансованого фіскального простору можуть зумовити поглиблення міжрегіональної диференціації та від'ємний вектор розвитку в межах окремих регіонів.

Висновки. Дослідження сутності та складників фіскального простору інклюзивного розвитку регіону як можливості органів місцевого самоврядування щодо акумулювання та нарощення 
фінансових ресурсів для здійснення оптимальних видатків, орієнтованих на максимізацію соціального добробуту на основі принципів інклюзивності, дає змогу поглибити розуміння цієї дефініції та ії цільової спрямованості. Авторське бачення фіскального простору пов'язує природу його формування з провадженням активної фіскальної політики, ефективністю функціонування бюджетної системи та ємністю податкового потенціалу. Виокремлення детермінант формування та розширення фіскального простору має велике значення для обгрунтування пріоритетів фінансової децентралізації, орієнтованої на зміцнення фінансової бази інклюзивного розвитку регіонів.

\section{Список використаних джерел:}

1. Heller P. Understanding Fiscal Space. IMF - Policy Discussion Paper. 2005. PDP/05/4. 19 p.

2. Ostry D. Jonathan, Ghosh R. Atish, Kim I. Jun, and Qureshi S. Mahvash Fiscal Space. IMF Staff Position Note SPN/10/11. 2010. URL : http://www.corrispondenti.net/documenti/FMI-020910.pdf (дата звернення: 15.11.2019).

3. Затонацька Т.Г., Ткаченко О.С. Теоретична сутність та особливості формування фіскального простору. Наукові записки Наџіонального університету «Острозька академія». 2016. № 3(31). С. 119-125.

4. Аджиева Л.А. Формирование эффективной бюджетно-налоговой политики региона в условиях развития федерализма в России : автореф. дис. ... канд. экон. наук : 08.00.10 ; ФГБОУ ВПО «Дагестанский государственный университет». Москва, 2013. 24 с.

5. Кузькін Є.Ю. Формування фіскального простору місцевого самоврядування в умовах децентралізації державних фінансів. Проблеми економіки. 2018. № 2. С. 328-334.

6. Хом'як М.С. Методичні підходи до визначення детермінант та оцінки розмірів фіскального простору регіонів. Економічний вісник Найіонального гірничого університету. 2016. № 3. С. 60-70.

7. Башуцька О. Податкове планування та прогнозування в системі податково-бюджетного регулювання. Наука й економіка. 2010. № 1(17). С. 7-10.

8. Супруненко С.А. Податковий потенціал у стратегічному податковому плануванні. Науковий вісник Міжнародного гуманітарного університету. Серія «Економіка і менеджмент». 2015. Вип. 13. С. 225-229.

9. Цимбалюк I.О., Редько I.М. Формування та оцінка податкового потенціалу регіонів України. Економічний вісник університету. 2013. Вип. 20/2. С. 216-221.

10. Павліха Н.В., Цимбалюк І.О., Уніга О.В. Розвиток та регулювання ринку праці прикордонного регіону : монографія. Луцьк : Вежа-Друк, 2018. 220 с.

\section{References:}

1. Heller P. (2005). Understanding Fiscal Space. IMF - Policy Discussion Paper. PDP/05/4. 19 p.

2. Ostry D. Jonathan, Ghosh R. Atish, Kim I. Jun, and Qureshi S. Mahvash (2010). Fiscal Space. IMF Staff Position Note SPN/10/11 Available at: http://www.corrispondenti.net/documenti/FMI-020910.pdf (accessed 15 November 2019).

3. Zatonatska T.H., Tkachenko O.Ye. (2016). Teoretychna sutnist ta osoblyvosti formuvannia fiskalnoho prostoru [Theoretical essence and peculiarities of fiscal space formation]. Naukovi zapysky Natsionalnoho universytetu «Ostrozka akademiia». Vol. 3(31). Pp. 119-125.

4. Adzhyeva L.A. (2013). Formyrovanye effektyvnoi biudzhetno-nalohovoi polytyky rehyona $v$ uslovyiakh razvytyia federalyzma $v$ Rossyy [The formation of an effective region fiscal policy in the context of the development of federalism in Russia]. (PhD Thesis), Moscow: «Dagestan State University».

5. Kuzkin Ye.Yu. (2018). Formuvannia fiskalnoho prostoru mistsevoho samovriaduvannia v umovakh detsentralizatsii derzhavnykh finansiv [Formation of fiscal space of local self-government under conditions of decentralization of public finances]. Problemy ekonomiky. Vol. 2. Pp. 328-334.

6. Khom'iak M.S. (2016). Metodychni pidkhody do vyznachennia determinant ta otsinky rozmiriv fiskalnoho prostoru rehioniv [Methodical approaches to determining and estimating the size of the fiscal space of the regions]. Economic Bulletin of the National Mining University. Vol. 3. Pp. 60-70.

7. Bashutska O. (2010). Podatkove planuvannia ta prohnozuvannia $v$ systemi podatkovo-biudzhetnoho rehuliuvannia. Nauka y ekonomika [Tax planning and forecasting in the system of fiscal regulation]. Vol. 1(17). Pp. 7-10.

8. Suprunenko S.A. (2015). Podatkovyi potentsial v stratehichnomu podatkovomu planuvanni [Tax potential in strategic tax planning]. Scientific Bulletin of the International Humanities University. Series: Economics and Management. Vol. 13. Pp 225-229.

9. Tsymbaliuk I.O., Redko I.M. (2013). Formuvannia ta otsinka podatkovoho potentsialu rehioniv Ukrainy [Formation and assessment of tax potential of Ukrainian regions]. Ekonomichnyi visnyk universytetu: zbirnyk naukovykh prats uchenykh ta aspirantiv. Vol. 20/2. Pp. 216-221.

10. Pavlikha N.V., Tsymbaliuk I.O., Uniha O.V. (2018). Rozvytok ta rehuliuvannia rynku pratsi prykordonnoho rehionu [Development and regulation of the labor market in the border region]. Lutsk: Vezha-Druk. (in Ukrainian) 
Tsymbaliuk Iryna

Lesya Ukrainka Eastern European National University

\section{THE ESSENCE AND COMPONENTS OF THE REGIONS' INCLUSIVE DEVELOPMENT FISCAL SPACE}

The development of the region as a spatial system is conditioned by the differentiation of public needs and requires the financial resources mobilization, the optimal budget expenditures implementation, and government borrowing within budgetary constraints, which in a significant way influences the processes of formation and emergence of fiscal space fluctuations. The purpose of the article is to determine the nature and components of the fiscal space of regions' inclusive development, to reveal the main determinants of its formation and to expand what are the guidelines and mechanisms of fiscal policy, budget order, and budget system, as well as the territory's tax potential. The systematic and logical-structural approaches were used in the study - in conceptualizing the fiscal space of regions' inclusive development; as well as methods of comparative analysis, systematization, and analogy - in revealing the nature and constituents of the study's object. The article describes the essence of the fiscal space of the region as a space of interaction between economic entities and self-government bodies regarding the redistribution of financial resources of the region. The determinants of the formation and expansion of the fiscal space of the region are determined, namely: guidelines and mechanisms of fiscal policy, budget order and structure of the budget system, the size of the territory's tax potential. In the context of financial decentralization, the expansion of the fiscal space of the region is achieved by increasing the real financial and legal capacity of local authorities, increasing the importance of their management decisions on the formation and use of budget resources, their ability to focus on enhancing inclusive development. Author's substantiated vision of the concept of "fiscal space for region's inclusive development" as opportunities for local governments to increase financial resources to achieve optimal expenditures focused on maximizing social wellbeing, achieved through a combination of economic stability, effective redistribution of regional budgets resources as a result of the socio-economic uplift of benefits. The practical significance of the study is that defining the nature and components of the fiscal space of an region's inclusive development allows us to deepen our understanding of this definition and its purpose.

Key words: fiscal space of the region, fiscal space of region's inclusive development, region's inclusive development, financial decentralization, fiscal policy, budgetary system, tax potential.

JEL classification: R58, H71, H73. 